carbohydrate impairment. Glucagon concentrations were not investigated.

Because of the potential diabetogenic properties of nifedipine plasma glucose concentrations should thus be monitored in patients receiving this drug.

We thank Dr J C Henquin for invaluable discussions and critical advice, and Mrs Detaille for secretarial help.

1 Opie LH. Drugs and the heart. Calcium antagonists. Lancet 1980;i:806-9.

${ }^{2}$ Koch G. Plasma renin activity, epinephrine and norepinephrine at rest and during exercise in young adults and boys. Scand $\mathcal{f}$ Clin Lab Invest $1977 ; 37$, suppl 147:107.

3 Giugliano D, Torella R, Cacciapuoti F, Gentile S, Verza M, Varriecho M. Impairment of insulin secretion in man by nifedipine. Eur $\mathfrak{f}$ Clin Pharmacol 1980;18:395-8.

(Accepted 18 March 1981)

Department of Internal Medicine, Division of Endocrinology and Nutrition, University Hospital St Luc and Unité de Diabete et Croissance, Faculty of Medicine-UCL 54.74, 1200 Brussels, Belgium

STANISLAS CHARLES, DM, research fellow

JEAN-MARIE KETELSLEGERS, DM, senior registrar

MARTIN BUYSSCHAERT, DM, senior registrar

ANDRE E LAMBERT, DM, professor of endocrinology

\section{Diagnosing tuberculous pleural effusion: comparative sensitivity of mycobacterial culture and histopathology}

Establishing the specific causal diagnosis of tuberculous pleural effusion remains difficult because of the low yield of mycobacteria from incubated horizontally for one week and vertically for eight weeks. They were inspected for growth daily during the first week and weekly thereafter. All positive cultures were examined microscopically to confirm the presence of acid-fast bacilli. They were tested for niacin production and all were confirmed to be Mycobacterium tuberculosis. For histopathology, the pleural tissue was fixed in $10 \%$ formalin, processed through graded alcohol and chloroform solutions, and embedded in paraffin. Sections of $5 \mu \mathrm{m}$ were cut, stained with hematoxylin-eosin, and examined for the presence of granulomas. In addition, $500-1000 \mathrm{ml}$ of pleural fluid was collected in $2.5 \%$ sodium citrate solution ( $3 \mathrm{ml}$ solution per $100 \mathrm{ml}$ fluid). The entire specimen was centrifuged at $3000 \mathrm{rpm}$ for 30 minutes and the sediment inoculated on to Lowenstein-Jensen culture medium.

Bacteriological or histopathological evidence of tuberculosis was obtained in 16 patients (see table); five patients had malignancy confirmed by pleural tissue histopathology; and in the remaining three no definite diagnosis could be reached. Among the 16 patients with tuberculosis, pleural tissue mycobacterial culture was positive in $14(88 \%)$ but histopathology showed granulomas in only nine $(56 \%)$. Pleural fluids from 11 patients were cultured and four $(36 \%)$ were positive. Sputum and gastric juice smears were positive for acid-fast bacilli in only one patient in whom the pleural tissue and fluid grew mycobacteria. In five patients the diagnosis could be made only by pleural tissue culture, in one only by pleural tissue histopathology, and in another only by pleural fluid culture.

\section{Comment}

Mycobacterial culture of pleural tissue was found to be the most sensitive test for the diagnosis of tuberculous pleural effusion. Histopathological examination of pleura was less sensitive, but it was more sensitive than pleural fluid culture. Histopathology gives an answer more quickly and may occasionally be the only positive clue. Moreover, it helps in the early diagnosis of malignancy. Mycobacterial culture takes more time but gives a definitive diagnosis in most cases. Therefore, we recommend that mycobacterial culture and histopathological examination of pleural tissue should be done in all patients suspected to have tuberculous pleural effusion.

We are grateful to Professor A Bhaktaviziam for help and guidance in histopathology, to Professor B M Pulimood and Professor Lily John for permission to study patients admitted under their care, and to Mrs Uma Mukundan for technical assistance.

Results of bacteriological and histopathological tests on 16 specimens of pleura

\begin{tabular}{|c|c|c|c|c|c|}
\hline \multirow{2}{*}{ Specimen No } & \multicolumn{2}{|c|}{ Pleural tissue } & \multicolumn{2}{|c|}{ Pleural fluid } & \multirow{2}{*}{$\begin{array}{c}\text { Sputum, gastric } \\
\text { juice, or both }\end{array}$} \\
\hline & $\begin{array}{c}\text { Mycobacterial } \\
\text { culture }\end{array}$ & $\begin{array}{c}\text { Histo- } \\
\text { pathology }\end{array}$ & $\begin{array}{l}\text { Smear test for } \\
\text { acid-fast bacilli }\end{array}$ & $\begin{array}{l}\text { Mycobacterial } \\
\text { culture }\end{array}$ & \\
\hline 1 & + & - & ND & ND & - \\
\hline 2 & + & + & - & - & - \\
\hline 3 & + & - & - & ND & - \\
\hline 4 & + & + & - & ND & ND \\
\hline 5 & + & - & - & ND & - \\
\hline 6 & + & - & - & ND & - \\
\hline 7 & + & + & - & - & - \\
\hline 8 & + & - & - & - & - \\
\hline 9 & + & - & - & + & - \\
\hline 10 & + & + & - & - & $\bar{n}$ \\
\hline 11 & - & - & - & + & ND \\
\hline 12 & + & + & - & + & - \\
\hline 13 & + & + & - & - & ND \\
\hline 14 & + & + & - & $\overline{-}$ & ND \\
\hline 15 & $\bar{t}$ & + & $\bar{t}$ & $\bar{t}$ & ND \\
\hline 16 & + & + & + & + & + \\
\hline $\begin{array}{l}\text { Total } \\
\text { No }(\%) \text { positive }\end{array}$ & $\begin{array}{c}16 \\
14(88)\end{array}$ & $9 \stackrel{16}{9(56)}$ & $\begin{array}{l}15 \\
1(7)\end{array}$ & $4(36)$ & 11 \\
\hline
\end{tabular}

sputum, gastric juice, and pleural fluid. Histopathological examination of pleura has been shown to give good results. ${ }^{1}$ Mycobacterial culture of pleural tissue has been described ${ }^{3}$ but has not become popular. ${ }^{4}$ We have compared the sensitivity of pleural tissue mycobacterial culture and histopathology in establishing the diagnosis of tuberculous pleural effusion.

\section{Patients, methods, and results}

Twenty-four consecutive patients admitted to hospital with their first episode of exudative pleural effusion from March 1979 to August 1980 were studied. Patients with obvious underlying disease were not included. Closed pleural biopsy was performed with Abrams's needle, and two specimens of pleura were obtained from each patient. One piece was processed for mycobacterial culture and the other for histopathological examination. The specimen for culture was sent to the laboratory in sterile saline. It was ground in Tefion tissue grinder and inoculated in blood agar, in thioglycollate broth, and on two slopes of Lowenstein-Jensen culture medium. The slopes were
1 Von Hoff DD, LiVolsi V. Diagnostic reliability of needle biopsy of the parietal pleura. Am f Clin Pathol 1975;64:200-3.

2 Scharer L, McClement JH. Isolation of tubercle bacilli from needle biopsy specimens of parietal pleura. Am Rev Respir Dis 1968;97:466-8.

${ }^{3}$ Levine H, Metzger W, Lacera D, Kay L. Diagnosis of tuberculous pleurisy by culture of pleural biopsy specimen. Arch Intern Med 1970; $126: 269-71$.

- Anonymous. Pleural effusion. Br Med $\mathcal{J} 1975$;iii:192-3.

5 Davies D, Smith WHR. Pleural effusion. Br Med f 1975;iii :543-4.

(Accepted 11 March 1981)

Christian Medical College and Hospital, Velore, Tamil Nadu 632004 India

SATISH KUMAR, MB, BS, registrar

M S SESHADRI, MD, lecturer in medicine

GRACE KOSHI, MD, DCP, professor and head of microbiology

T JACOB JOHN, PHD, FRCP, professor of microbiology 